\title{
Effects of Short-Term Treatment with Recombinant Human Growth Hormone on Carbamazepine Pharmacokinetics in Rats
}

\author{
Yuh-Jing Lin, Yann-Huei Phillip Lee and William R Ravis* \\ Department of Pharmacal Sciences, Harrison School of Pharmacy, Auburn University, USA
}

\begin{abstract}
Objectives: To investigate the pharmacokinetics of Carbamazepine (CBZ) in rats during growth hormone treatment.

Methods: Recombinant Human Growth Hormone ( $\mathrm{rhGH}$ ) was injected subcutaneously at a daily dose of $0.1 \mathrm{mg} /$ $\mathrm{kg}, 2 \mathrm{mg} / \mathrm{kg}$, or phosphate buffered saline (control) for 5 days in male Sprague-Dawley rats. On day 6, a dose of 25 $\mathrm{mg} / \mathrm{kg}$ of CBZ was injected intravenously via a jugular vein cannula into the rat. Growth rate were compared between treatment groups. The pharmacokinetics of CBZ was determined from its concentrations in rats' blood and urinary samples.
\end{abstract}

Results: Over the 5-day treatment period, growth rate were greater than control for the $2 \mathrm{mg} / \mathrm{kg}$ rhGH dosed group. The volume of distribution $\left(\mathrm{V}_{\mathrm{ss}}\right)$ was significantly $(\mathrm{p}<0.05)$ decreased in the high dosed $\mathrm{hGH}$ rats compared to the control group. Total body clearance $(\mathrm{CL})$ in the $2 \mathrm{mg} / \mathrm{kg}$ rhGH group was also significantly $(p<0.05)$ decreased compared with the control group $(0.497 \pm 0.076 \mathrm{~L} / \mathrm{hr} / \mathrm{kg}$ vs $0.685 \pm 0.109 \mathrm{~L} / \mathrm{hr} / \mathrm{kg})$. Urinary data showed that renal and metabolic clearances were both significantly $(p<0.05)$ decreased in the $2 \mathrm{mg} / \mathrm{kg}$ rhGH group.

Conclusions: A dose dependent effect of rhGH was observed on growth rates and $\mathrm{CBZ}$ pharmacokinetics in rats. After 5 days $\mathrm{rhGH}$ treatment, the volume of distribution of $\mathrm{CBZ}$ was significantly changed in the $2 \mathrm{mg} / \mathrm{kg} / \mathrm{day}$ rhGH treated groups. In the $2 \mathrm{mg} \mathrm{rhGH} / \mathrm{kg}$ treated rats, both renal and metabolic clearance of CBZ were also significantly decreased compared with the control group. Similar decreases in volume of distribution and both clearances may suggest the interaction may involve increased $\mathrm{CBZ}$ plasma protein binding during $\mathrm{rhGH}$ treatment in rats.

Keywords: Human Growth Hormone; Carbamazepine; Pharmacokinetics; Rats

\section{Introduction}

Human Growth Hormone (hGH) is secreted by somatotrophs of the anterior pituitary and produced by monocytes. It can stimulate the rate of protein synthesis in cells, increase the number of cells, and consequently increase the growth of numerous tissues in the body. Also, hGH elevates the level of glucose and fatty acids in plasma, decreases lipogenesis in liver, and increases the concentration of minerals in tissues. Somatropine (Humatrope by Eli Lilly) is a Recombinant Human Growth Hormone (rhGH) synthesized by Escherichia coli using genetic engineering techniques. It was approved by the FDA for the treatment of pituitary dwarfism in children, Turner's syndrome and other forms of growth retardation, as well as HIV-associated wasting. Alternative uses of rhGH include body building, catabolism, female infertility, obesity, and osteoporosis. Growth hormone is also used for increasing milk production and lean/fat ratios in veterinary medicine. However, rhGH is sometimes misused by athletes and children for enhancing competitive advantages. It is reported that rhGH alters the muscle/fat ratio as a consequence of increasing protein synthesis, lipolysis, and fatty acids oxidation and also affects hepatic enzymes activity [1-7]. Most studies have examined drug metabolizing enzyme changes with rhGH replacement in growth hormone deficient animals and humans and not the influence of supplemental dosing [811]. Supplemental rhGH has the potential to alter the pharmacokinetic profile of drugs. Although there are several studies examining drug metabolizing enzyme changes following rhGH, there is little known with regard to induced pharmacokinetic changes.

Carbamazepine (CBZ) is the drug of choice for generalized tonic-clonic and complex partial seizures, trigeminal neuralgia, and bipolar disorder [12,13]. Carbamazepine has a low hepatic extraction ratio $(<0.2)$ and is $60 \%$ to $80 \%$ bound to plasma protein [13]. The four major metabolic pathways of CBZ in humans are the epoxide pathway, aromatic hydroxylation, direct N-glucuronidation, and sulfur-containing conjugation, and metabolites from these pathways constitute $40 \%, 25 \%, 15 \%$, and $5 \%$ of urinary excreted drug, respectively. The epoxide pathway is mediated by cytochrome P450, such as CPY3A4 and CPY2B, which can be induced by the repeated administration of CBZ to both humans and animals [1419], leading to increased metabolic clearance. CBZ metabolism and pharmacokinetics can be altered by many drugs, such as phenytoin and phenobarbital which increase CBZ clearance and other drugs as cimetidine, erythromycin, and isoniazid, which inhibit the activity of the cytochrome P450 system, decreasing the clearance of CBZ [14-16]. The active metabolite, CBZ-epoxide, can also induce these enzymes in rats during multiple doses [17-19]. Thus, CBZ has been chosen as a model drug to investigate the effects of supplemental growth hormone on drug metabolism and pharmacokinetics.

Rats have been utilized as a model to study the physiologic and growth effects of growth hormone [2,20-29]. It has been reported that rhGH injections given in the morning to the rats show a better growth effect than injections given in the evening [20]. Also, pulsatile administration is more effective than continuous administration [21], and rhGH absorption after subcutaneous injection is better

*Corresponding author: William R Ravis, Department of Pharmacal Sciences Harrison School of Pharmacy, Auburn University, Auburn, Alabama 36849, USA Tel: 334-844-8325; Fax: 334-844-8331; E-mail: raviswr@auburn.edu

Received March 06, 2013; Accepted September 20, 2013; Published September 27,2013

Citation: Lin YJ, Lee YHP, Ravis WR (2013) Effects of Short-Term Treatment with Recombinant Human Growth Hormone on Carbamazepine Pharmacokinetics in Rats. Clin Exp Pharmacol 3: 132. doi:10.4172/2161-1459.1000132

Copyright: (c) 2013 Lin YJ, et al. This is an open-access article distributed under the terms of the Creative Commons Attribution License, which permits unrestricted use, distribution, and reproduction in any medium, provided the original author and source are credited. 
than intramuscular injection [22]. It has been reported that there are differences in the number and types of GH receptors between male and female rats [23-26]. Hypophysectomy can cause changes in the GH receptors, glomerular filtration rate [27-29], and liver enzyme activity [2] in rats. In this present study, rhGH was given subcutaneously to normal rats once daily in the morning at doses as has been previously reported for physiologic and growth investigations.

\section{Materials and Methods}

Recombinant Human Growth Hormone (rhGH, Lot 979 HG9) was a generous gift from Eli Lilly (Indianapolis, IN). Carbamazepine was purchased from Sigma Co. (St. Louis, MO). All the other reagents were purchased from Fisher Scientific (Pittsburgh, PA).

\section{Growth effect}

Pretreatment: Sprague-Dawley male rats (170-190 g, Harlan Sprague Dawley Inc. Indianapolis, IN) were housed in the Biological Research Laboratory of Auburn University approved by the Institutional Animal Care and Use Committee (IACUC). The room temperature was maintained at $25^{\circ} \mathrm{C}$ and the light-dark cycle was 12 hours each. Food and tap water were available ad libitum. During this pretreatment time, rats were handled and weighed every day.

Treatment (Day1-Day5): As soon as the bodyweights of rats reached the desired weight, $210 \pm 10 \mathrm{~g}$, they were divided into two groups, control or treatment groups. Recombinant Human Growth Hormone (rhGH) was dissolved in $\mathrm{pH} 7$ phosphate saline buffer. Two doses of 0.1 and $2 \mathrm{mg} / \mathrm{kg} \mathrm{rhGH}$ were given to investigate the dose-dependent effect. The treatment group was injected with rhGH subcutaneously every morning at the back of neck for 5 days while the control group was received PBS instead. The bodyweights of rats were recorded daily.

\section{Pharmacokinetics study (Day6)}

Cannulation: In the morning of day 6, after $5 \mathrm{rhGH}$ injections in 5 days of treatment period, a jugular cannula was placed on the rat's neck and exited at the back of neck. A harness was also placed on the rats to protect the cannula. The cannula was flashed with heparin (50 unit/ $\mathrm{mL}$ ) to ensure the opening.

Dosing: Three hours after the surgery, rats recovered completely from surgery. Carbamazepine was injected through the cannula into the vein at a dose of $25 \mathrm{mg} / \mathrm{kg}$ based on the bodyweight at day 6 .

Sampling: Blood samples were drawn at $0.6,1,1.5,2,3,4,5,6$, and 8 hours after dosing. Plasma was obtained by centrifuging the blood samples at $3000 \mathrm{rpm}$ for 5 minutes (DYNAC II Centrifuge, Clay Adams) and stored at $-80^{\circ} \mathrm{C}$ until analysis. Urine samples were collected at 8 and 24 hours after dosing. The volume of urine was recorded and urinary samples were stored in freezer until analysis.

Analysis: Plasma and urine samples were thawed completely before analysis. A TDx (Abbott Diagnostic, Abbott Park, IL) analyzer was used to determine the concentrations of $\mathrm{CBZ}$ in the samples. This assay system is based on fluorescence polarization technique. The calibration range was $0.0-20.0 \mu \mathrm{g} / \mathrm{mL}$ and the sensitivity was $0.5 \mu \mathrm{g} / \mathrm{mL}$.

\section{Calculations}

\section{Calculations for weight changes}

The percent bodyweight gain (\%Gain) in 5 days was calculated as:

$\%$ Gain in 5 days $=($ BWT6 - BWT1 $) /$ BWT1 ${ }^{*} 100 \%$ (Eq.1)

Where BWT6 was the rat's bodyweight on the day 6 (after 5 days' rhGH injections), and the BWT1 was the bodyweight on the day 1 (at the first rhGH injection). The average growth rate (Rate) during the treatment was calculated as:

$$
\text { Rate }=(\text { BWT6 }- \text { BWT1) } / 5 \text { days (Eq. 2) }
$$

Pharmacokinetics analysis: Carbamazepine plasma concentrations were analyzed with model independent method (non-compartmental analysis) by WinNonlin 5.2 computer program (Pharsight, Cary, NC). The terminal rate constant (lambda_z) was determined by linear regression of the natural logarithm (LN) of CBZ concentration versus time from the terminal decline in plasma concentrations. The elimination half-life $\left(\mathrm{T}_{1 / 2}\right)$ was calculated as 0.693 / lambda_z. The area under the drug concentrations versus time curve (AUC) and its first moment (AUMC) were estimated by the linear trapezoidal rule with the last portion estimated to infinity by using lambda_z. The total body clearance $(\mathrm{CL})$ was determined by Dose/AUC and the mean residence time (MRT) as AUMC/AUC. The steady-state volume of distribution $\left(\mathrm{V}_{\mathrm{ss}}\right)$ was calculated as $\mathrm{V}_{\mathrm{ss}}=\mathrm{MRT}{ }^{\star} \mathrm{CL}$ and the volume of distribution based on area $\left(\mathrm{V}_{\text {area }}\right)$ was determined as $\mathrm{V}_{\text {area }}=\mathrm{CL} /$ lambda_z.

For the urinary parameters of $\mathrm{CBZ}$, the fraction excreted unchanged in urine (fe) was calculated by $\mathrm{fe}=\mathrm{A}_{\mathrm{u}, 24} /$ Dose where $\mathrm{A}_{\mathrm{u}, 24}$ was the total urinary excreted $\mathrm{CBZ}$ in 24 hours. The renal clearance $\left(\mathrm{CL}_{\mathrm{r}}\right)$ was obtained by $\mathrm{CL}_{\mathrm{r}}=\mathrm{fe}{ }^{\star} \mathrm{CL}$ and metabolic clearance $\left(\mathrm{CL}_{\mathrm{m}}\right)$ was calculated as $\mathrm{CL}_{\mathrm{m}}=\mathrm{CL}-\mathrm{CL}_{\mathrm{r}}$.

Statistical analysis: The influence of treatment and period on the variables of weight gain and the pharmacokinetic parameters were evaluated by analysis of variance procedures (GLM, SAS Institute, Cary, NC). Significant difference were accepted at $\mathrm{P}<0.05$ level. Multiple comparisons were performed by a Bonferroni approach (SAS Institute, Cary, NC).

\section{Results}

\section{Growth effect of rhGH}

Table 1 shows the weight gains and the comparisons of average growth rates between control groups and rhGH treated groups. There was no significant differences between the $0.1 \mathrm{mg} / \mathrm{kg}$ rhGH treated group and the control in either weight gain (\%Gain) in 5 days or the average daily growth rates (Rate). However, in the $2 \mathrm{mg} / \mathrm{kg} \mathrm{rhGH}$ group, there was a significant $(\mathrm{p}<0.01)$ increase in the percent body

\begin{tabular}{|c|c|c|c|}
\hline rhGH mg/kg & $\mathrm{n}$ & $\% \mathrm{G}$ in 5 days $^{\mathrm{a}}$ Mean $\pm \mathrm{SD}$ & Rate $^{\mathrm{b}}(\mathrm{g} /$ day $)$ Mean $\pm \mathrm{SD}$ \\
\hline 0 & 8 & $10.7 \pm 2.9$ & $5.1 \pm 1.5$ \\
\hline 0.1 & 6 & $11.6 \pm 1.8$ & $5.4 \pm 0.7$ \\
\hline 2 & 8 & $14.7 \pm 2.6^{\text {cd }}$ & $6.7 \pm 1.2^{\text {cd }}$ \\
\hline
\end{tabular}

a $\% \mathrm{G}$ in 5 days $=($ weight gain after 5 days $) /($ body weight on day 1$) * 100$

b Rate $=$ weight gain after 5 days $/ 5$ days

c Significantly different from control group, $\mathrm{P}<0.01$

d Significantly different from $0.1 \mathrm{mg} / \mathrm{kg}$ rhGH group, $\mathrm{P}<0.01$

Table 1: Percent weight gain and average daily growth rate in male rats receiving $5 \mathrm{rhGH}$ once a day injection. 
weight gain $(14.7 \pm 2.6 \% v s 10.7 \pm 2.9 .0 \%)$ and the average growth rates $(6.7 \pm 1.2 \mathrm{~g} /$ day $v s 5.1 \pm 1.5 \mathrm{~g} /$ day) comparing the treated group with the control group.

Also, there were significant differences on comparing the two rhGH treated groups by both \%Gain and Rates. The group treated with the higher $\mathrm{rhGH}$ dose $(2 \mathrm{mg} / \mathrm{kg} \mathrm{rhGH})$ showed a significantly $(\mathrm{p}<0.01)$ greater \%Gain compared with the low rhGH dose $(14.6 \pm 2.6 \%$ vs 11.6 $\pm 1.8 \%)$ as well as in the average daily growth rate (Rate) $(6.7 \pm 1.2 \mathrm{~g} /$ day $v s 5.4 \pm 0.7 \mathrm{~g} /$ day).

\section{Pharmacokinetics study}

The CBZ plasma concentrations versus time following a 25 $\mathrm{mg} / \mathrm{kg} \mathrm{CBZ}$ dose in the treatment groups are presented in Figure 1. Pharmacokinetic parameters are reported based upon noncompartmental analysis for IV bolus administration.

Pharmacokinetic parameters are listed in Table 2. There were significant $(\mathrm{p}<0.05)$ differences between the $0.1 \mathrm{mg} / \mathrm{kg}$ rhGH treated groups and the control groups with respect to half-life $\left(\mathrm{T}_{1 / 2}\right)$ and volume of distribution $\left(\mathrm{V}_{\text {area }}\right)$. At the doses of $0.1 \mathrm{mg} / \mathrm{kg} \mathrm{rhGH}$, no effect of rhGH was noted on CBZ clearance (CL), AUC, or mean residence time $(\mathrm{MRT})$ in rats. However, the AUC was increased significantly $(\mathrm{p}<0.05)$ in the $2 \mathrm{mg} / \mathrm{kg}$ group compared with the control group (49.5 vs 35.1 $\mu \mathrm{g} \mathrm{hr} / \mathrm{mL})$ and $0.1 \mathrm{mg} / \mathrm{kg}$ rhGH group $(38.2 \mu \mathrm{g} \mathrm{hr} / \mathrm{mL})$. The total body clearance (CL) in $2 \mathrm{mg} / \mathrm{kg}$ rhGH treated group decreased significantly $(\mathrm{p}<0.05)$ compared to control group and the $0.1 \mathrm{mg} / \mathrm{kg}$ treated group (0.497 vs 0.685 and $0.654 \mathrm{~L} / \mathrm{hr} / \mathrm{kg}$, respectively). Both assessments of CBZ volumes of distribution $\left(\mathrm{V}_{\text {area }}\right.$ and $\left.\mathrm{V}_{\mathrm{ss}}\right)$ were significantly $(\mathrm{p}<0.05)$ reduced in $2.0 \mathrm{mg} / \mathrm{kg} \mathrm{rhGH}$ treated rats compared to the control group. $\mathrm{V}_{\text {ss }}$ was $0.990 \pm 0.249 \mathrm{~L} / \mathrm{kg}$ for the high dose rhGH animals compared to $1.37 \pm 0.18 \mathrm{~L} / \mathrm{kg}$ for control animals.

The CBZ urinary excretion results and renal clearance $\left(\mathrm{CL}_{\mathrm{r}}\right)$ are also shown in Table 2 . For rats dosed at $0.1 \mathrm{mg} / \mathrm{kg} \mathrm{rhGH}$, there was no difference for $\mathrm{CBZ} \mathrm{CL}_{\mathrm{r}}$ and $\mathrm{CL}_{\mathrm{m}}$ between control and treated rats. However, there was a significant $(\mathrm{p}<0.05)$ decrease in $\mathrm{CBZ} \mathrm{CL}_{\mathrm{r}}$ in $2 \mathrm{mg} /$ $\mathrm{kg} \mathrm{rhGH}$ treated rats compared to the control group $(0.0135 \pm 0.0019$ vs $0.0175 \pm 0.0037 \mathrm{~L} / \mathrm{hr} / \mathrm{kg})$. Also, $\mathrm{CBZ}$ metabolic clearance $\left(\mathrm{CL}_{\mathrm{m}}\right)$ for $2 \mathrm{mg} / \mathrm{kg}$ group was significantly $(\mathrm{p}<0.05)$ less compared to its control group $(0.484$ vs $0.667 \mathrm{~L} / \mathrm{hr} / \mathrm{kg})$.

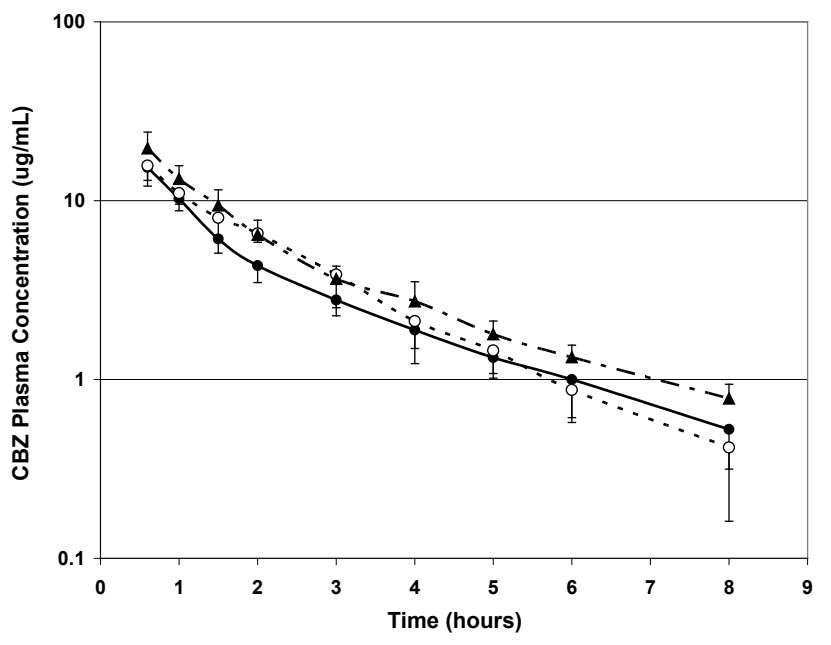

Figure 1: CBZ plasma concentrations in control $(\bullet)$ and 5 day $0.1 \mathrm{mg} / \mathrm{kg}(\circ)$ and $2.0 \mathrm{mg} / \mathrm{kg}(\mathbf{\Delta}) \mathrm{rhGH}$ treated rats.

\begin{tabular}{|c|c|c|c|}
\hline Parameters & $\begin{array}{c}\text { Control }(\mathrm{n}=8) \\
\text { Mean } \pm \mathrm{SD}\end{array}$ & $\begin{array}{c}\text { rhGH 0.1 mg/kg }(\mathrm{n}=6) \\
\text { Mean } \pm \mathrm{SD}\end{array}$ & $\begin{array}{c}\text { rhGH } 2 \mathrm{mg} / \mathrm{kg}(\mathrm{n}=8) \\
\text { Mean } \pm \text { SD }\end{array}$ \\
\hline $\mathrm{T}_{1 / 2}(\mathrm{hr})$ & $1.86 \pm 0.32$ & $1.30 \pm 0.22^{\mathrm{b}}$ & $1.72 \pm 0.10^{\mathrm{c}}$ \\
\hline $\mathrm{MRT}(\mathrm{hr})$ & $2.03 \pm 0.33$ & $1.70 \pm 0.43$ & $1.97 \pm 0.26$ \\
\hline $\mathrm{AUC}_{\mathrm{t}}\left(\mu \mathrm{g}^{*} \mathrm{hr} / \mathrm{mL}\right)$ & $35.1 \pm 4.6$ & $38.2 \pm 6.9$ & $49.5 \pm 8.2^{\mathrm{bc}}$ \\
\hline $\mathrm{AUC}\left(\mu \mathrm{g}^{*} \mathrm{hr} / \mathrm{mL}\right)$ & $37.3 \pm 5.5$ & $39.3 \pm 6.8$ & $51.4 \pm 8.4^{\mathrm{bc}}$ \\
\hline $\mathrm{V}_{\text {area }}(\mathrm{L} / \mathrm{kg})$ & $1.80 \pm 0.17$ & $1.21 \pm 0.21^{\mathrm{b}}$ & $1.23 \pm 0.22^{\mathrm{b}}$ \\
\hline $\mathrm{V}_{\mathrm{ss}}(\mathrm{L} / \mathrm{kg})$ & $1.37 \pm 0.19$ & $1.10 \pm 0.29$ & $0.990 \pm 0.249^{\mathrm{b}}$ \\
\hline $\mathrm{CL}(\mathrm{L} / \mathrm{hr} / \mathrm{kg})$ & $0.685 \pm 0.109$ & $0.654 \pm 0.119$ & $0.497 \pm 0.076^{\mathrm{bc}}$ \\
\hline $\mathrm{CL}_{\mathrm{r}}(\mathrm{L} / \mathrm{hr} / \mathrm{kg})$ & $0.0175 \pm 0.0037$ & $0.0136 \pm 0.0050$ & $0.0135 \pm 0.0091^{\mathrm{b}}$ \\
\hline $\mathrm{CL}_{\mathrm{m}}(\mathrm{L} / \mathrm{hr} / \mathrm{kg})$ & $0.667 \pm 0.105$ & $0.643 \pm 0.171$ & $0.484 \pm 0.075^{\mathrm{b}}$ \\
\hline $\mathrm{fe}$ & $0.0254 \pm 0.0026$ & $0.0206 \pm 0.0048$ & $0.0274 \pm 0.0040$ \\
\hline
\end{tabular}

a $T_{1 / 2}=$ half-life; $M R T=$ mean residence time; $\mathrm{AUC}_{\mathrm{t}}=$ area under the plasma curve to the last concentration; $\mathrm{AUC}_{*}=$ area under the plasma curve to the infinity; $\mathrm{V}_{\text {are }}$ = apparent volume of distribution; $\mathrm{V}_{\mathrm{ss}}=$ apparent volume of distribution at steady state; $\mathrm{CL}=$ total body clearance; $\mathrm{CL}_{\mathrm{r}}=$ renal clearance; $\mathrm{CL}_{\mathrm{m}}=$ metabolic clearance; $\mathrm{fe}=$ fraction excreted unchanged

b Significantly different from control group, $p<0.05$

c Significantly different from the $\mathrm{rhGH} 0.1 \mathrm{mg} / \mathrm{kg} /$ day group, $\mathrm{p}<0.05$

Table 2: Comparison of carbamazepine ( $25 \mathrm{mg} / \mathrm{kg}$ IV) pharmacokinetics in male rats receiving rhGH for 5 days.

\section{Discussion}

Recombinant Human Growth Hormone (rhGH) has been shown to increase body weight by increasing cell numbers and cell sizes in all body tissues [7]. In this study, body weight gains during rhGH injections were used to verify the growth effects of rhGH. The growth effect was evaluated by comparing growth rates in rhGH treated animals with control animals which received phosphate buffer saline injections. Dose-effect relationships were examined by comparing physical and pharmacokinetic results between the two rhGH doses $(0.1$ and $2 \mathrm{mg} / \mathrm{kg}$ )

\section{Growth effect of rhGH}

Compared with the control group, the dose of $0.1 \mathrm{mg} \mathrm{rhGH} / \mathrm{kg}$ (weight gain of 11.6\%) did not demonstrate effective growth effects whereas the $2 \mathrm{mg}$ rhGH (weight gain of 14.7\%) showed a significant growth effect in treated rats. There was a dose effect observed in growth rates and weight gains between the two rhGH doses $(0.1$ and $2 \mathrm{mg} /$ $\mathrm{kg}$ /day) during these 5 days of rhGH treatments. The average daily growth rate was significantly greater in the $2 \mathrm{mg} / \mathrm{kg}$ group $(6.7 \mathrm{~g} /$ day $)$ compared to the $0.1 \mathrm{mg} / \mathrm{kg}$ group $(5.4 \mathrm{~g} /$ day). The significant total weight gain in 5 days was reflected by the significantly increased daily growth rates in the $2 \mathrm{mg} / \mathrm{kg}$ rhGH treated rats.

During our studies, it was observed that there was a decreased in daily growth rates in rats receiving phosphate buffer saline injections (control group) and low rhGH dose compared to non-injected animals during the pretreatment period ( $6.3 \pm 0.5 \mathrm{~g}$ per day in 10 rats). It was assumed that the low body weight gains in these two groups were due to the irritation and discomfort caused by injections. These observed decreases in body weight in rats were consistent with the results of Silence's study [20] which noted decreases in weight gain in control injected rats.

\section{Pharmacokinetics of carbamazepine}

Rats have been frequently used as a model to investigate factors altering CBZ pharmacokinetics. Most of the pharmacokinetic reports of CBZ in rats employed HPLC methods; however, similar pharmacokinetic parameters were observed in this present study using fluorescence polarization techniques. In male rats, $67 \%$ of the injected parent drug administered as ${ }^{14} \mathrm{C}-\mathrm{CBZ}$ is recovered as total (parent drug 
and metabolites) within 120 hours in urine (29\%) and feces (38\%) [30]. In this present study, the fraction excreted of unchanged CBZ in the urine had mean values of $2.1-2.7 \%$ in the treatment groups. The reported apparent volume of distribution for CBZ in rats ranges from 1.4 to $1.7 \mathrm{~L} / \mathrm{kg}$ without significant differences between adults, young, old, and pregnant animals [30-32]. The volumes of distribution $\left(\mathrm{V}_{\mathrm{ss}}=\right.$ $1.80 \pm 0.17 \mathrm{~L} / \mathrm{kg}$ ) noted in the control animals is within this range. The CL for CBZ in male control rats of $0.685 \pm 0.109 \mathrm{~L} / \mathrm{kg}$ is similar to previously reported values. There are reported significant differences in drug clearance between male $(0.96 \mathrm{~L} / \mathrm{hr} / \mathrm{kg})$ and female $(0.56 \mathrm{~L} / \mathrm{hr} / \mathrm{kg})$, as well as between young $(0.72 \mathrm{~L} / \mathrm{hr} / \mathrm{kg})$ and old $(0.32 \mathrm{~L} / \mathrm{hr} / \mathrm{kg})$ rats [ 30 , 31]. The $\mathrm{CBZ} \mathrm{T}_{1 / 2}$ of 1.86 hours in the control group found in this study is comparable to values reported by others for rats [31-35].

On treating rats with rhGH, volumes of distribution changes were observed, particularly in the high dose $(2 \mathrm{mg} / \mathrm{kg})$. CBZ volumes of distribution decreased in both dosing groups. In the case of animals dosed with $2 \mathrm{mg} / \mathrm{kg}, \mathrm{V}_{\mathrm{ss}}$ decreased by $28 \%$. This could be a result of alteration in drug tissue ratios, blood flow, organ size, and/or plasma protein binding. Fat/muscle tissue ratio may be changed during rhGH treatment [10]. The plasma protein binding of CBZ is $60 \%$ to $80 \%$ in rats [36]. It is reported that rhGH can alter the amount and plasma concentrations of albumin in humans [37,38], depending on the dose and the duration of the growth hormone treatments. Also, growth hormone has been shown to increase albumin concentrations in rats [39].

The half-life of CBZ is decreased upon repeated CBZ administration from $1.2(1.0-1.3)$ hours to $0.8(0.6-1.0)$ hours in male rats and from $1.8(1.5-2.2)$ hours to $1.0(0.8-1.2)$ hours in female rats [31]. The half-life of 1.86 hours in control group found in this study is similar to values reported by others for rats [30-35]. In the present study, the total body clearance of CBZ significantly decreased in $2 \mathrm{mg} / \mathrm{kg} \mathrm{rhGH}$ treated rats compared to control rats and $0.1 \mathrm{mg} / \mathrm{kg}$ rhGH treated rats, by approximately $27 \%$ and $24 \%$, respectively. The half-lives were decreased with $0.1 \mathrm{mg} / \mathrm{kg}$ treatment due to the decreases in volumes of distribution and no change in clearance. On the other hand, in the $2 \mathrm{mg} / \mathrm{kg}$ rhGH group, the decreases in volume of distribution with a decrease in clearance yielded no change in half-life.

By utilizing the urinary data, it was possible to separately evaluate changes in renal and metabolic clearance. In rats, the largest portion of CBZ is biotransformed to CBZ-epoxide by the microsomal epoxidation pathway [14]; however, in humans, about $90 \%$ of CBZepoxide is further metabolized to 10,11-transdiol by epoxide hydrolase [14]. Tateishi et al. [19] suggested that there are more enzymes, such as CYP 2C6 and CYP 2C11, that are involved in CBZ metabolism in rats than in human. Metabolic clearance showed no effect of rhGH dosing at $0.1 \mathrm{mg} / \mathrm{kg}$ but was decreased by $27 \%$ in animals dosed at 2 $\mathrm{mg} / \mathrm{kg}$. A decrease in $\mathrm{CL}_{\mathrm{m}}$ could result from inhibition or reduction of drug metabolizing enzyme activity or decreased drug plasma protein binding. This is opposite to what has been noted in most studies were rhGH increases hepatic and drug metabolizing enzyme activity [1-11]. Without further analyzing all the metabolites in urine, it is not possible to determine if there was a change in $\mathrm{CBZ}$ metabolic pattern resulting from rhGH treatment.

Renal clearance showed a decreasing trend in the low rhGH group and was significantly less $(23 \%)$ for the high dose treated animals. Information on the potential effects of rhGH on renal function is limited and evaluations may be complicated by changes in creatinine metabolism [10]. A decrease in $\mathrm{CBZ} \mathrm{CL}_{\mathrm{r}}$ could reflect altered glomerular filtration, tubular reabsorption, or plasma protein binding. The fraction excreted unchanged (fe) was similar in all groups suggesting that $\mathrm{CL}_{\mathrm{m}}$ and $\mathrm{CL}_{\mathrm{r}}$ were changing or decreasing in the same direction equally. Decreases in both $\mathrm{CL}_{\mathrm{m}}$ and $\mathrm{CL}_{\mathrm{r}}$ resulted in CL being $27 \%$ lower in 2 $\mathrm{mg} / \mathrm{kg}$ rhGH rats than the control group.

The interactions between supplemental rhGH treatment and CBZ drug disposition appears to be complex with alterations in drug distribution, $\mathrm{CL}_{\mathrm{r}}$ and $\mathrm{CL}_{\mathrm{m}}$. Following rhGH treatments, altered amounts and plasma concentrations of albumin have been noted in humans [37, 38] and rats [39]. It is possible that, in this study, the albumin was increased by the rhGH treatment. Unfortunately, sample volumes were not large enough to assess either drug plasma protein binding or albumin concentrations. Such an increase in protein binding would decrease the fraction free (ff) of drug in plasma and thus, decrease the organ clearances $\left(\mathrm{CL}_{\mathrm{r}}, \mathrm{CL}_{\mathrm{m}}\right)$. For a low extraction ratio drug such as CBZ (extraction ratio $<0.2)[13], \mathrm{CL}_{\mathrm{r}}$ and $\mathrm{CL}_{\mathrm{m}}$ will be proportioned to $\mathrm{ff}$. This increase in drug plasma protein binding would lead to similar decreases in $\mathrm{CL}_{\mathrm{r}}$ and $\mathrm{CL}_{\mathrm{m}}$ with no change in fe, as seen in this study. In addition, a decrease in $\mathrm{ff}$ would result in decreases in volumes of distribution as noted in this study, particularly in the high rhGH dosing group. Consequently, the half-life $\left(\mathrm{T}_{1 / 2}=0.693 \mathrm{~V} / \mathrm{CL}\right)$ would not be affected since volume of distribution and clearance both decreased. Interestingly, volume of distribution appeared to decrease with no decrease in clearances in the lower rhGH dose group resulting in a short $\mathrm{T}_{1 / 2}$. Since protein binding of CBZ was not determined in this study, further studies of drug protein binding changes during rhGH treatment or therapy might be considered. This drug interaction may have several mechanisms and the significance of the pharmacokinetic changes depend on the rhGH dose or exposure.

\section{Conclusion}

In conclusion, after 5 days of $2 \mathrm{mg} / \mathrm{kg}$ rhGH subcutaneous injections, the body weight gain in male Sprague-Dawley rats was significantly increased, demonstrating the growth effects of rhGH. In the group of rats that received $0.1 \mathrm{mg} / \mathrm{kg}$ rhGH for 5 days, there was no difference in weight gains; however, the half-life and the volume of distribution $\left(\mathrm{V}_{\text {area }}\right.$ ) of CBZ $(25 \mathrm{mg} / \mathrm{kg}$, IV) were decreased compared to control. The pharmacokinetics of CBZ $(25 \mathrm{mg} / \mathrm{kg}$, IV) was altered by 5 days of $2 \mathrm{mg} / \mathrm{kg}$ rhGH injections resulting in a significantly decreased total body clearance (CL) and volume of distribution at steady-state $\left(\mathrm{V}_{\mathrm{ss}}\right)$. Decrease in renal and metabolic clearances as well as in volume of distribution in the group of $2 \mathrm{mg} / \mathrm{kg}$ rhGH treated rats suggest that the interaction mechanism may involve increases in CBZ plasma protein binding following rhGH treatment in rats.

\section{Acknowledgement and Funding}

Authors would like to express their sincere appreciation toward Eli Lilly \& Company (Indianapolis, IN) for their generous gift of the recombinant human growth hormone used in this study. This research received no specific grant from any funding agency in the public, commercial, or not-for-profit sectors.

\section{References}

1. Levitsky LL, Schoeller DA, Lambert GH, Edidin DV (1989) Effect of growth hormone therapy in growth hormone-deficient children on cytochrome P-450 dependent 3-N-demethylation of caffeine as measured by the caffeine ${ }^{13} \mathrm{CO}_{2}$ breath test. Dev Pharmacol Ther 12: 90-95.

2. Wong BS, Dunn A (1977) Possible growth hormone regulation of rat liver glutamine synthetase activity. Biochem Biophys Res Commun 79: 876-884.

3. Schaffer WT (1985) Effects of growth hormone on lipogenic enzyme activities in cultured rat hepatocytes. Am J Physiol 248: E719-725.

4. Newman JD, Armstrong JM, Bornstein J (1978) Effects of part sequences of human growth hormone on in vivo hepatic glycogen metabolism in the rat. Biochim Biophy Acta 544: 234-244. 
Citation: Lin YJ, Lee YHP, Ravis WR (2013) Effects of Short-Term Treatment with Recombinant Human Growth Hormone on Carbamazepine Pharmacokinetics in Rats. Clin Exp Pharmacol 3: 132. doi:10.4172/2161-1459.1000132

5. Ma GYW, Macaulay SL, Maggs JA, Armstrong JM, Bornstein J (1982) The mechanism of the hyperglycemic action of synthetic peptides related to the C-terminal sequence of human growth hormone. Biochim Biophys Acta 716: 400-409.

6. Bornstein J, Ng FM, Heng D, Wong KP (1983) Metabolic actions of pituitary growth hormone and acetyl CoA carboxylase by human growth hormone and a carboxyl terminal part sequence acting through a second messenger. Acta Endocrinol 103: 479-486.

7. Parker KL, Schimmer BP (2006) Pituitary hormones and their hypothalamic releasing factors. In: Brunton LL eds. Goodman \& Gilman's the pharmacological basis of therapeutics. $11^{\text {th }}$ edn. McGraw-Hill, New York.

8. Redmond GP, Bell JJ, Nichola PS, Perel JM (1980) Effect of growth hormone on human drug metabolism: time course and substrate specificity. Pediatr Pharmacol 1: 63-70.

9. Wilson JT (1970) Alteration of normal development of drug metabolism by injection of growth hormone. Nature 225: 861-863.

10. Strobl JS, Thomas MJ (1994) Human growth hormone. Pharmacol Rev 46: 1-34.

11. Shapiro BH, Agrawal AK, Pampaori NA (1995) Gender differences in drug metabolism regulated by growth hormone. Int J Biochem Cell Biol 27: 9-20.

12. Guyton AC, Hall JE (2006) Textbook of Medical Physiology. 11th edn. Saunders, Philadelphia.

13. Johanessen SI, Gerna M, Bakke J, Strandjord RE, Morselli PL (1976) CSF concentrations and serum protein binding of carbamazepine and carbamazepine 10,11-2poxide in epileptic patients. Br J Clin Pharmacol 3: 575-582.

14. Faigle JW, Feldmann KF (1995) Carbamazepine. Chemistry and Biotransformation. In: Levy RH et al. eds. Antiepileptic drugs. 4th edn. Raven Press, New York

15. Giaccone M, Bartoli A, Gatti G, Marchiselli R, Pisani F, et al. (1996) Effect of enzyme inducing anticonvulsants on exthosuximide pharmacokinetics in epileptic patients. Br J Clin Pharmacol 41: 575-579.

16. Bertilsson L, Tybring G, Widén J, Chang M, Tomson T (1997) Carbamazepine treatment induces the CYP3A4 catalyzed sulphoxidation of omeprazole, but has no or less effect on hydroxylation via CYP2C19. Br J Clin Pharmacol 44: 186-189.

17. Panesar SK, Bandiera SM, Abbott FS (1996) Comparative effects of carbamazepine and carbamazepine-10,11-epoxide on hepatic cytochromes P450 in the rat. Drug Metab Dispos 24: 619-627.

18. Kerr BM, Thummel KE, Wurden CJ, Klein SM, Kroetz DL, et al. (1994) Human liver carbamazepine metabolism Role of CYP3A4 and CYP2C8 in 10,11-epoxide formation. Biochem Pharmacol 47: 1969-1979.

19. Tateishi T, Asoh M, Nakura H, Watanabe M, Tanaka M, et al. (1999) Carbamazepine induces multiple cytochrome $\mathrm{P} 450$ subfamilies in rats. Chem Biol Interact 117: 257-268.

20. Sillence MN, Etherton TD (1989) Changes in serum concentrations of ACTH corticosterone and in growth following morning or evening injection of female ratswith porcine growth hormone. J Endocrinol 123: 113-119.

21. Clark RG, Jansson JO, Isaksson O, Robinson IC (1985) Intravenous growth hormone: growth responses to patterned infusions in hypophysectomized rats. J Endocrinol 104: 53-61.

22. Jorgensen KD, Monrad JD, Brøndum L, Dinesen B (1988) Pharmacokinetics of biosynthetic and pituitary human growth hormone in rats. Pharmacol Toxicol 63: $129-134$

23. Ranke MB, Stanley CA, Rodbard D, Baker L, Bongiovanni A, et al. (1976) Sex differences in binging of human growth hormone to isolated rat hepatocytes. Proc Natl Acad Sci USA 73: 847-851.
24. Postel-Vinay MC, Kayser C, Desbuquois B (1982) Fate of injected human growth hormone in the female rat liver in vivo. Endocrinology 111: 244-251.

25. Herington AC, Veith NM (1977) The presence of lactogen but not growth hormone binding in the isolated rat hepatocytes. J Endocrinol 74: 323-334.

26. Posner BI, Kelly PA, Friesen HG (1974) Induction of a lactogen receptor in rat liver: influence of estrogen and the pituitary. Proc Natl Acad Sci USA 71: 2407-2410.

27. Gause I, Eden S (1986) Induction of growth hormone (GH) receptors in adipocytes of hypophysectomized rats by GH. Endocrinology 118: 119-124.

28. Kelly PA, Posner BI, Friesen HG (1975) Effects of hypophysectomy, ovariectomy, and cycloheximide on specific binding sites for lactogenic hormones in rat liver. Endocrinology 97: 1408-1415.

29. Bullier-Picard F, Postel-Vinay MC (1984) Hypophysectomy and growth hormone receptors in liver membranes of male rats. Endocrinology 114: 1328-1333.

30. Morseli PL (1975) Carbamazepine: absorption, distribution and excretion. Adv Neurol 11: 279-293.

31. Farghali-Hassan, Assael BM, Bossi L, Garattini S, Gerna M, et al. (1976) Carbamazepine pharmacokinetics in young, adult and pregnant rats. Relation to pharmacological effects. Arch Int Pharmacodyn Ther 220: 125-139.

32. Conti I, Guiso G, Urso R, Caccia S (1987) Inhibitory and inducing effects of dezimol on carbamazepine metabolism in the rats. Pharmacology 35: 241-248.

33. Ni J, Ouyang H, Aiello M, Seto C, Borbridge L, et al. (2008) Microdosing assessment to evaluate pharmacokinetics and drug metabolism in rats using liquid chromatography-tandem mass spectrometry. Pharm Res 25: 1572-1582.

34. Graumlich JF, McLaughlin RG, Birkhahn D, Shah N, Burk A, et al. (1999) Carbamazepine pharmacokinetics-pharmacodynamics in genetically epilepsyprone rats. Eur J Pharmacol 369: 305-311.

35. Remmel RP, Sinz MW, Cloyd JC (1990) Dose-dependent pharmacokinetics of carbamazepine in rats: determination of the formation clearance of carbamazepine-10,11-epoxide. Pharm Res 7: 513-517.

36. Brueguerolle B, Valli M, Bouyard L, Jadot G, Bouyard P (1981) Circadian effect on carbamazepine kinetics in rats. Eur J Drug Metab Pharmacokinet 6: 189 193.

37. Li N, Zhang B, Dong P, Lin W, Wang H, et al. (2008) Recombinant human growth hormone increases albumin and prolongs survival in patients with chronic liver failure: a pilot open, randomized, and controlled clinical trial. Dig Liver Dis 40: 554-559.

38. Graham MR, Baker JS, Evans P, Kicman A, Cowan D, et al. (2007) Shortterm recombinant human growth hormone administration improves respiratory function in abstinent anabolic-androgenic steroid users. Growth Horm IGF Res 17: 328-335.

39. Basoglu M, Kiziltunc A, Yildirgan MI, Gumustekin K, Gumus M, et al. (2002) Recombinant human growth hormone modulates the hepatic acute-phase response and $\mathrm{P}$-selectin in burned rats. Burns 28: 760-764. 